\title{
Potential pathway of anti-inflammatory effect by New Zealand honeys
}

\author{
This article was published in the following Dove Press journal: \\ International Journal of General Medicine \\ 5 March 2014 \\ Number of times this article has been viewed
}

\author{
Victoria Tomblin' \\ Lynnette R Ferguson' \\ Dug Yeo Han' \\ Pamela Murray' \\ Ralf Schlothauer ${ }^{2}$ \\ 'Discipline of Nutrition, Faculty of \\ Medical and Health Sciences, The \\ University of Auckland, Auckland, \\ New Zealand; ${ }^{2}$ Comvita New \\ Zealand Ltd, Paengaroa, New Zealand
}

Correspondence: Lynnette R Ferguson; Dug Yeo Han

Discipline of Nutrition, Faculty of Medical and Health Sciences, The University of Auckland, Private Bag 92019, Auckland I I 42, New Zealand

Email l.ferguson@auckland.ac.nz; dy.han@auckland.ac.nz
Abstract: The role of honey in wound healing continues to attract worldwide attention. This study examines the anti-inflammatory effect of four honeys on wound healing, to gauge its efficacy as a treatment option. Isolated phenolics and crude extracts from manuka (Leptospermum scoparium), kanuka (Kunzea ericoides), clover (Trifolium spp.), and a manuka/kanuka blend of honeys were examined. Anti-inflammatory assays were conducted in HEK-Blue ${ }^{\mathrm{TM}}-2$, HEK-Blue ${ }^{\mathrm{TM}}-4$, and nucleotide oligomerization domain (NOD)2-Wild Type (NOD2-WT) cell lines, to assess the extent to which honey treatment impacts on the inflammatory response and whether the effect was pathway-specific. Kanuka honey, and to a lesser extent manuka honey, produced a powerful anti-inflammatory effect related to their phenolic content. The effect was observed in HEK-Blue ${ }^{\mathrm{TM}}-2$ cells using the synthetic tripalmitoylated lipopeptide Pam3CysSerLys4 (Pam3CSK4) ligand, suggesting that honey acts specifically through the toll-like receptor (TLR)1/TLR2 signaling pathway. The manuka/kanuka blend and clover honeys had no significant anti-inflammatory effect in any cell line. The research found that kanuka and manuka honeys have an important role in modulating the inflammatory response associated with wound healing, through a pathway-specific effect. The phenolic content of honey correlates with its effectiveness, although the specific compounds involved remain to be determined.

Keywords: Leptospermum scoparium, manuka, Kunzea ericoides, kanuka, Trifolium, clover, inflammatory response, phenolics, wound healing

\section{Introduction}

Honey has long been used as a natural treatment in wound repair and has increased in popularity with antibiotic resistance increase. ${ }^{1-4}$ Honey is effectual and costeffective, and its healing properties are well documented. ${ }^{5-6}$ Honey can decrease healing time via a dual effect on the inflammatory response. It suppresses the production and proliferation of inflammatory cells at the wound site, to prevent a prolonged inflammatory response, and it stimulates proinflammatory cytokine production, enabling normal healing to occur. ${ }^{7-11}$ Wound healing is a tissue remodeling process, comprising a systematic progression of events involving multiple interactions that are regulated by biologically active cytokines, growth factors, and proteases. ${ }^{12-15}$ The transcription factor nuclear factor-kappa beta (NF-KB) is an important marker of inflammation. ${ }^{16}$ It enhances proinflammatory activity, thereby contributing to an amplified inflammatory response, and activates genes encoding for proinflammatory cytokines - interleukin (IL)-6, IL-8, and tumor necrosis factor- $\alpha$ (TNF- $\alpha){ }^{8,17}$ These proinflammatory cytokines stimulate nitric oxide production, an important mediator of inflammation. Nitric oxide production 
and NF-KB activation are inhibited by the flavonoids present in honey. ${ }^{18}$ When healing is impaired, chronic wounds develop, characterized by proinflammatory cytokines and reactive oxygen species. ${ }^{8,19-22}$

Honey's effectiveness in wound care has been hypothesized to be largely due to its anti-inflammatory action. ${ }^{8}$ The specific compounds and the mechanisms involved are largely undetermined. ${ }^{23}$ However, it has been suggested that specific polyphenols, the flavonoids, and caffeic acid phenethyl ester, are important factors. ${ }^{24-26}$ The antioxidants found in honey are considered to be important determinants of its anti-inflammatory activity. ${ }^{2}$ An elevated inflammatory response results from hydrogen peroxide oxygen radicals present at the wound site, triggering NF-KB to enhance the inflammatory response. ${ }^{2,8} \mathrm{New}$ Zealand honeys have been suggested to display significant antiinflammatory activity, particularly kanuka and manuka honeys, by reducing neutrophil superoxide production. ${ }^{23}$ Manuka honey has been shown to specifically decrease the inflammatory response associated with ulcerative colitis, an inflammatory bowel disease characterized by an overexpression of inflammatory cells, possibly by increasing antioxidant activity. ${ }^{27-29}$

Several studies have investigated the anti-inflammatory activity of New Zealand honeys in treating topical wounds. This study further investigated the anti-inflammatory properties of manuka and kanuka honey, and demonstrates the effectiveness of these New Zealand honeys in reducing the inflammatory response associated with healing, independent of its known topical effect. Furthermore, specific signaling pathways, through which these honeys are effective, were observed.

\section{Materials and methods Preparation of honey extracts}

Four New Zealand honeys were used - manuka, kanuka, a manuka/kanuka blend (all supplied by Comvita New Zealand Ltd, Te Puke, NZ), and clover honey (supplied by Airborne Honey Ltd, Leeston, NZ). Honey extracts were fractionated by Dr Peter Brooks (University of the Sunshine Coast, Sippy Downs, QLD, Australia) to isolate their phenolic compounds. The percentages of phenolics were determined (manuka 59\%, kanuka 39\%, the manuka/kanuka blend 59\%, and clover $40 \%$ ). They were stored at $4{ }^{\circ} \mathrm{C}$. Both phenolic and crude extracts were tested. Figure 1 depicts the process flow for the preparation of the following materials and the accompanying observation steps.

\section{Reagents}

HEK-Blue ${ }^{\mathrm{TM}}$-2, HEK-Blue ${ }^{\mathrm{TM}}-4$, and nucleotide oligomerization domain (NOD)2-Wild Type (NOD2-WT) embryonic kidney cell lines were selected due to their accessibility and relatively high expression of matrix metalloproteinase (MMP)-1, -2, and -9. These were obtained from the Auckland Cancer Society Research Centre (Auckland, NZ). Dulbecco's Modified Eagle's Medium (DMEM), an antibiotic mixture (penicillin, streptomycin, L-glutamine), and fetal calf serum (FCS) were obtained from Life Technologies Corp (Carlsbad, CA, USA). Phorbol 12-myristate 13-acetate (PMA) and ibuprofen were purchased from Sigma-Aldrich Corp (St Louis, MO, USA). Lipopolysaccharide (LPS), Pam3CysSerLys4 (Pam3CSK4), and FSL-1 (Pam2CGDPKHPKSF, a synthetic diacylated lipoprotein), Muramyl dipeptide (MDP), Blasticidin, Zeocin ${ }^{\mathrm{TM}}$, HEK-Blue ${ }^{\mathrm{TM}}$ Selection, and QUANTI-Blue ${ }^{\mathrm{TM}}$ were from InvivoGen (San Diego, CA, USA). Cell Proliferation Reagent WST-1 was obtained from Roche Applied Science (Penzberg, Germany).

\section{Cell culture}

The HEK-Blue ${ }^{\mathrm{TM}}-2$ and HEK-Blue ${ }^{\mathrm{TM}}-4$ cells were maintained in DMEM high glucose supplemented with $10 \%$ FCS, $1 \%$ penicillin/streptomycin/glutamine, and HEK-Blue ${ }^{\mathrm{TM}}$ Selection. The NOD2 WT cells were maintained in DMEM supplemented with $10 \%$ FCS, $1 \%$ penicillin/streptomycin, $0.06 \%$ Blasticidin, and $0.1 \%$ Zeocin.

\section{Anti-inflammatory assay}

The HEK-Blue ${ }^{\mathrm{TM}}-2$ and HEK-Blue ${ }^{\mathrm{TM}}-4$ cells were seeded at $1 \times 10^{5}$ cells $/ \mathrm{mL}$ and the NOD2 WT cells at $5 \times 10^{5}$ cells $/ \mathrm{mL}$, into 96-well plates, and incubated for 24 hours at $37^{\circ} \mathrm{C}, 5 \% \mathrm{CO}_{2}$. The honey extracts, at a suitable dose range $(5.3 \%-14.3 \%)$ as determined by preliminary half maximal inhibitory concentration $\left(\mathrm{IC}_{50}\right)$ data, and the controls (75 mM Ibuprofen, $1 \mathrm{mg} / \mathrm{mL}$ PMA, and a solvent control) were added to the plate and further incubated for 24 hours. The appropriate ligand for each cell line was added (3.125 $\mu \mathrm{g} / \mathrm{mL}$ LPS, $10 \mathrm{ng} / \mathrm{mL}$ Pam3CSK4, $10 \mathrm{ng} / \mathrm{mL}$ FSL-1, and $22.73 \mu \mathrm{g} / \mathrm{mL}$ MDP), and all were incubated for 24 hours. The secreted embryonic alkaline phosphatase (SEAP) production was measured, using QUANTI-Blue, every 10 minutes for 50 minutes. Cell viability was determined by WST-1 after 60-, 90-, and 120-minute incubations. The results were normalized for cell viability and against a solvent control. 


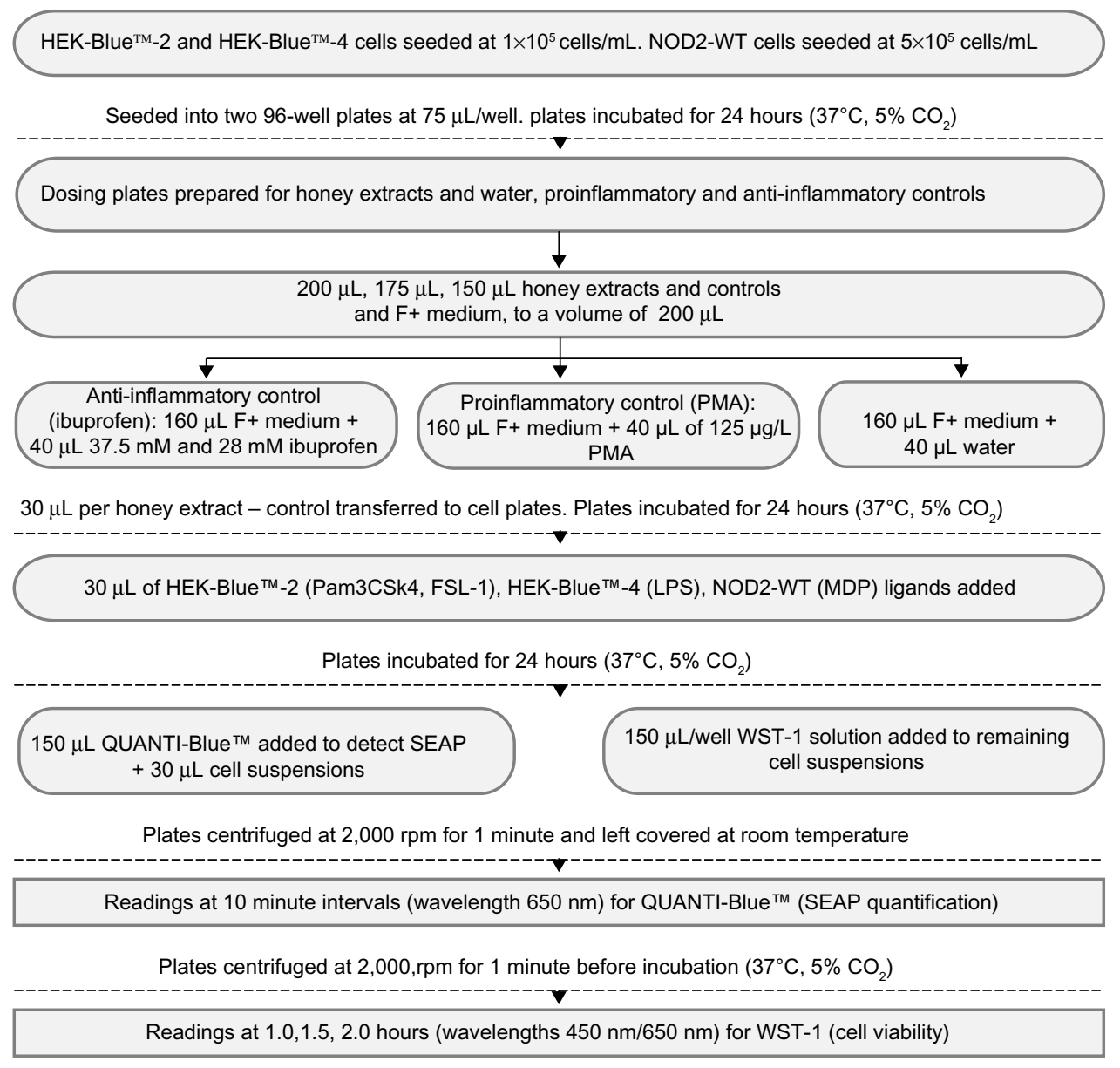

Figure I Materials, preparation, and observation process flow chart.

Note: HEK-Bluet ${ }^{\mathrm{T} M}-2$ and QUANTI-Blue ${ }^{\mathrm{TM}}$ (InvivoGen, San Diego, CA, USA).

Abbreviations: LPS, lipopolysaccharide; MDP, muramyl dipeptide; NOD2-WT, nucleotide oligomerization domain 2-Wild Type; PMA, phorbol I2-myristate 13-acetate; SEAP, secreted alkaline phosphatase; Pam3CSK4, Pam3CysSerLys4; FSL-I, Pam2CGDPKHPKSF.

\section{Statistical analysis}

A generalized linear model was fitted to test the antiinflammatory effect of eight honey extracts at five different concentrations (\% honey) compared with untreated cells, in the presence of the specific ligand corresponding to the cell line. The means with standard error and estimates with 95\% confidence interval along with $P$-value were calculated. Table 1 provides the anti-inflammatory effect of the honey extracts at five different concentrations ( $\%$ honey) compared with untreated cells, in the HEK-Blue ${ }^{\mathrm{TM}}-4$ cell line using the LPS ligand. Table 2 provides the anti-inflammatory effect of the honey extracts at five different concentrations compared with untreated cells, in the HEK-Blue ${ }^{\mathrm{TM}}-2$ cell line using the FSL-1 ligand. Table 3 provides the anti-inflammatory effect of the honey extracts at five different concentrations compared with untreated cells, in the HEK-Blue ${ }^{\text {TM}}-2$ cell line using the Pam3CSK 4 ligand. Table 4 provides the anti-inflammatory effect of the honey extracts at five different concentrations compared with untreated cells, in the NOD2-WT cell line using the MDP ligand. Figure 1 provides the materials, preparation, and observation process flow. Figure 2 provides the anti-inflammatory effect of the four honey extracts when differentiated by honey phenolic and crude honey extract. The units were expressed as SEAP relative to the control (\%). The higher the value, the higher was the level of SEAP, resulting in a lower anti-inflammatory effect. A $P$-value of less than 0.05 indicated that a significant anti-inflammatory effect was observed in those cells treated with honey compared with those cells that were not. All analyses were carried out using SAS $^{\circledR} 9.3$ (SAS Institute, Cary, NC, USA).

\section{Results \\ Effect of honey extracts on inflammation in HEK-Blue ${ }^{\mathrm{TM}}-4$ cells}

The honey extracts were analyzed in the HEK-Blue ${ }^{\mathrm{TM}_{-} 4}$ cell line in the presence of LPS. Table 1 details their 
Table I The anti-inflammatory effect of honey extracts at five different concentrations (\% honey) compared with untreated cells, in the HEK-Blue ${ }^{\mathrm{TM}}-4$ cell line using the LPS ligand

\begin{tabular}{|c|c|c|c|c|}
\hline Honey treatment & Concentration (\%) & Mean (SE) & Estimate $(95 \% \mathrm{Cl})$ & $P$-value \\
\hline \multirow[t]{6}{*}{ Phenolic manuka } & 0.0 & $1.04(0.01)$ & 0.0 & \\
\hline & 5.3 & $1.00(0.05)$ & $-0.039(-0.1$ II to 0.034$)$ & 0.2713 \\
\hline & 7.1 & $0.94(0.01)$ & $-0.096(-0.168$ to -0.024$)$ & 0.0131 \\
\hline & 10.7 & $0.99(0.04)$ & $-0.050(-0.123$ to 0.022$)$ & 0.1579 \\
\hline & 12.5 & $0.98(0.03)$ & $-0.053(-0.126$ to 0.019$)$ & 0.1371 \\
\hline & 14.3 & $0.91(0.06)$ & $-0.125(-0.198$ to -0.053$)$ & 0.0024 \\
\hline \multirow[t]{6}{*}{ Phenolic kanuka } & 0.0 & $1.06(0.03)$ & 0.0 & \\
\hline & 5.3 & $1.03(0.02)$ & $-0.036(-0.1 I 3$ to $0.04 I)$ & 0.3310 \\
\hline & 7.1 & $0.95(0.02)$ & $-0.112(-0.189$ to -0.035$)$ & 0.0077 \\
\hline & 10.7 & $0.97(0.02)$ & $-0.097(-0.174$ to -0.020$)$ & 0.0173 \\
\hline & 12.5 & $0.98(0.07)$ & $-0.085(-0.162$ to -0.007$)$ & 0.0340 \\
\hline & 14.3 & $0.98(0.05)$ & $-0.087(-0.164$ to -0.010$)$ & 0.0300 \\
\hline \multirow[t]{6}{*}{ Phenolic manuka/kanuka } & 0.0 & $0.98(0.04)$ & 0.0 & \\
\hline & 5.3 & I.0I (0.05) & $0.029(-0.042$ to 0.099$)$ & 0.3982 \\
\hline & 7.1 & $0.97(0.02)$ & $-0.008(-0.078$ to 0.063$)$ & 0.8218 \\
\hline & 10.7 & $0.99(0.05)$ & $0.010(-0.060$ to 0.080$)$ & 0.7716 \\
\hline & 12.5 & $0.98(0.05)$ & $0.0(-0.070$ to $0.07 I)$ & 0.9889 \\
\hline & 14.3 & $0.97(0.05)$ & $-0.003(-0.073$ to 0.068$)$ & 0.9402 \\
\hline \multirow[t]{6}{*}{ Phenolic clover } & 0.0 & $0.97(0.06)$ & 0.0 & \\
\hline & 5.3 & $1.02(0.02)$ & $0.050(-0.037$ to 0.136$)$ & 0.2393 \\
\hline & 7.1 & $1.02(0.03)$ & $0.054(-0.032$ to $0.14 I)$ & 0.1983 \\
\hline & 10.7 & $1.05(0.05)$ & $0.078(-0.008$ to 0.165$)$ & 0.0731 \\
\hline & 12.5 & $1.06(0.04)$ & 0.093 (0.007 to 0.180$)$ & 0.0360 \\
\hline & 14.3 & $1.04(0.06)$ & $0.071(-0.015$ to 0.158$)$ & 0.0988 \\
\hline \multirow[t]{6}{*}{ Crude manuka } & 0.0 & $1.00(0.06)$ & 0.0 & \\
\hline & 5.3 & $0.99(0.04)$ & $-0.009(-0.084$ to 0.065$)$ & 0.7934 \\
\hline & 7.1 & I.0I (0.04) & $0.003(-0.072$ to 0.077$)$ & 0.9411 \\
\hline & 10.7 & $1.00(0.02)$ & $-0.001(-0.075$ to 0.074$)$ & 0.9853 \\
\hline & 12.5 & $1.03(0.04)$ & $0.024(-0.051$ to 0.098$)$ & 0.5072 \\
\hline & 14.3 & $0.98(0.05)$ & $-0.025(-0.099$ to 0.050$)$ & 0.4916 \\
\hline \multirow[t]{6}{*}{ Crude kanuka } & 0.0 & $0.95(0.07)$ & 0.0 & \\
\hline & 5.3 & $1.00(0.01)$ & $0.057(-0.011$ to 0.125$)$ & 0.0956 \\
\hline & 7.1 & $1.01(0.03)$ & $0.063(-0.006$ to 0.131$)$ & 0.0691 \\
\hline & 10.7 & $1.02(0.04)$ & 0.074 (0.005 to 0.142$)$ & 0.0362 \\
\hline & 12.5 & $1.03(0.03)$ & 0.084 (0.016 to 0.152$)$ & 0.0193 \\
\hline & 14.3 & $1.02(0.04)$ & $0.069(0.001$ to 0.137$)$ & 0.0485 \\
\hline \multirow[t]{6}{*}{ Crude manuka/kanuka } & 0.0 & $0.98(0.05)$ & 0.0 & \\
\hline & 5.3 & $0.99(0.04)$ & 0.011 ( -0.055 to 0.078$)$ & 0.7170 \\
\hline & 7.1 & $0.96(0.04)$ & $-0.019(-0.085$ to 0.047$)$ & 0.5478 \\
\hline & 10.7 & $0.96(0.02)$ & $-0.011(-0.077$ to 0.055$)$ & 0.7235 \\
\hline & 12.5 & I.0I (0.02) & $0.039(-0.027$ to 0.105$)$ & 0.2302 \\
\hline & 14.3 & $1.00(0.01)$ & $0.026(-0.040$ to 0.092$)$ & 0.4069 \\
\hline \multirow[t]{6}{*}{ Crude clover } & 0.0 & $1.00(0.05)$ & 0.0 & \\
\hline & 5.3 & $1.00(0.01)$ & $-0.006(-0.056$ to 0.044$)$ & 0.7903 \\
\hline & 7.1 & $\mathrm{I} .03(0.0 \mathrm{I})$ & $0.027(-0.023$ to 0.077$)$ & 0.2631 \\
\hline & 10.7 & $1.04(0.03)$ & $0.038(-0.013$ to 0.088$)$ & 0.1299 \\
\hline & 12.5 & $1.05(0.03)$ & $0.042(-0.008$ to 0.092$)$ & 0.0919 \\
\hline & 14.3 & $\mathrm{I} .03(0.0 \mathrm{I})$ & $0.030(-0.020$ to 0.080$)$ & 0.2211 \\
\hline
\end{tabular}

Abbreviations: $\mathrm{Cl}$, confidence interval; LPS, lipopolysaccharide; SE, standard error.

anti-inflammatory effect. No substantive effect was observed with treatment by any of the extracts. Following an increase in honey concentration, a noticeable anti-inflammatory effect was observed with the higher concentrations of the phenolic and crude kanuka extracts. The manuka phenolic extract produced a significant effect at the $7.1 \%(P=0.0131)$ and $14.3 \%(P=0.0024)$ concentrations. No significant difference was observed between both the manuka/kanuka blend and clover honeys and untreated cells at any concentration, with the exception of the $12.5 \%$ concentration of the phenolic clover extract $(P=0.0360)$. 
Table 2 The anti-inflammatory effect of honey extracts at five different concentrations (\% honey) compared with untreated cells, in the HEK-Blue ${ }^{\mathrm{TM}}-2$ cell line using the FSL-I ligand

\begin{tabular}{|c|c|c|c|c|}
\hline Honey treatment & Concentration (\%) & Mean (SE) & Estimate $(95 \% \mathrm{Cl})$ & $P$-value \\
\hline \multirow{6}{*}{ Phenolic manuka } & 0.0 & $1.10(0.12)$ & 0.0 & \\
\hline & 5.3 & $1.14(0.05)$ & $0.039(-0.121$ to 0.198$)$ & 0.5833 \\
\hline & 7.1 & $1.12(0.01)$ & $0.016(-0.143$ to 0.176$)$ & 0.8137 \\
\hline & 10.7 & $1.06(0.06)$ & $-0.044(-0.204$ to 0.115$)$ & 0.5324 \\
\hline & 12.5 & $\mathrm{I} .14(0.06)$ & $0.031(-0.129$ to 0.190$)$ & 0.6635 \\
\hline & 14.3 & $0.98(0.09)$ & $-0.123(-0.282$ to 0.036$)$ & 0.1109 \\
\hline \multirow[t]{6}{*}{ Phenolic kanuka } & 0.0 & $1.09(0.19)$ & 0.0 & \\
\hline & 5.3 & $1.13(0.12)$ & $0.032(-0.262$ to 0.326$)$ & 0.8068 \\
\hline & 7.1 & $1.24(0.15)$ & $0.142(-0.152$ to 0.436$)$ & 0.2915 \\
\hline & 10.7 & $0.98(0.06)$ & $-0.117(-0.411$ to 0.177$)$ & 0.3772 \\
\hline & 12.5 & $0.91(0.13)$ & $-0.182(-0.476$ to 0.112$)$ & 0.1862 \\
\hline & 14.3 & $0.78(0.08)$ & $-0.315(-0.609$ to -0.021$)$ & 0.0390 \\
\hline \multirow[t]{6}{*}{ Phenolic manuka/kanuka } & 0.0 & $1.17(0.08)$ & 0.0 & \\
\hline & 5.3 & $1.23(0.05)$ & $0.058(-0.27 \mathrm{I}$ to 0.387$)$ & 0.6884 \\
\hline & 7.1 & $\mathrm{I} .45(0.3 \mathrm{I})$ & $0.277(-0.052$ to 0.606$)$ & 0.0868 \\
\hline & 10.7 & $1.20(0.04)$ & $0.026(-0.304$ to 0.355$)$ & 0.8596 \\
\hline & 12.5 & $1.08(0.13)$ & $-0.097(-0.426$ to 0.233$)$ & 0.5104 \\
\hline & 14.3 & $0.99(0.07)$ & $-0.187(-0.516$ to 0.142$)$ & 0.2209 \\
\hline \multirow[t]{6}{*}{ Phenolic clover } & 0.0 & $1.11(0.19)$ & 0.0 & \\
\hline & 5.3 & $1.27(0.20)$ & 0.161 ( -0.240 to 0.562$)$ & 0.3739 \\
\hline & 7.1 & $1.49(0.25)$ & $0.380(-0.021$ to 0.781$)$ & 0.0600 \\
\hline & 10.7 & $\mathrm{I} .24(0.08)$ & $0.130(-0.27 \mid$ to $0.53 I)$ & 0.4675 \\
\hline & 12.5 & $\mathrm{I} .24(0.0 \mathrm{I})$ & $0.132(-0.269$ to 0.533$)$ & 0.4613 \\
\hline & 14.3 & $0.97(0.13)$ & $-0.142(-0.543$ to 0.259$)$ & 0.4308 \\
\hline \multirow[t]{6}{*}{ Crude manuka } & 0.0 & $\mathrm{I} .08(0.02)$ & 0.0 & \\
\hline & 5.3 & $0.99(0.00)$ & $-0.091(-0.376$ to 0.194$)$ & 0.4756 \\
\hline & 7.1 & $1.06(0.02)$ & -0.02 I $(-0.306$ to 0.264$)$ & 0.8645 \\
\hline & 10.7 & $0.88(0.10)$ & $-0.203(-0.488$ to 0.082$)$ & 0.1364 \\
\hline & 12.5 & $0.79(0.06)$ & $-0.292(-0.577$ to -0.006$)$ & 0.0462 \\
\hline & 14.3 & $1.09(0.12)$ & $0.014(-0.271$ to 0.299$)$ & 0.9099 \\
\hline \multirow[t]{6}{*}{ Crude kanuka } & 0.0 & $1.06(0.08)$ & 0.0 & \\
\hline & 5.3 & $1.15(0.05)$ & $0.085(-0.302$ to 0.472$)$ & 0.6202 \\
\hline & 7.1 & $1.19(0.13)$ & $0.121(-0.266$ to 0.508$)$ & 0.4836 \\
\hline & 10.7 & I.II (0.04) & $0.043(-0.344$ to 0.430$)$ & 0.8003 \\
\hline & 12.5 & $0.97(0.25)$ & $-0.090(-0.477$ to 0.297$)$ & 0.5983 \\
\hline & 14.3 & $1.31(0.10)$ & $0.244(-0.144$ to 0.631$)$ & 0.1804 \\
\hline \multirow[t]{6}{*}{ Crude manuka/kanuka } & 0.0 & $1.15(0.10)$ & 0.0 & \\
\hline & 5.3 & I.II (0.II) & -0.04 I ( -0.324 to 0.242$)$ & 0.7439 \\
\hline & 7.1 & $1.18(0.07)$ & $0.029(-0.254$ to 0.312$)$ & 0.8150 \\
\hline & 10.7 & $0.88(0.15)$ & $-0.262(-0.545$ to 0.021$)$ & 0.0649 \\
\hline & 12.5 & $1.16(0.08)$ & $0.009(-0.274$ to 0.292$)$ & 0.9437 \\
\hline & 14.3 & $1.29(0.06)$ & $0.139(-0.145$ to 0.422$)$ & 0.2849 \\
\hline \multirow[t]{6}{*}{ Crude clover } & 0.0 & $1.08(0.09)$ & 0.0 & \\
\hline & 5.3 & $1.10(0.03)$ & $0.013(-0.209$ to 0.236$)$ & 0.8902 \\
\hline & 7.1 & I.I3 (0.04) & $0.048(-0.174$ to 0.270$)$ & 0.6250 \\
\hline & 10.7 & $0.95(0.04)$ & $-0.133(-0.355$ to 0.089$)$ & 0.1986 \\
\hline & 12.5 & I.II (0.II) & $0.028(-0.194$ to 0.250$)$ & 0.7733 \\
\hline & 14.3 & $1.22(0.02)$ & $0.135(-0.087$ to 0.357$)$ & 0.1936 \\
\hline
\end{tabular}

Abbreviations: $\mathrm{Cl}$, confidence interval; SE, standard error; FSL-I, Pam2CGDPKHPKSF.

\section{Effect of honey extracts on inflammation in HEK-Blue ${ }^{\mathrm{TM}}-2$ cells}

Honey treatment was investigated in HEK-Blue ${ }^{\mathrm{TM}}-2$ cells in the presence of two ligands, FSL-1 and Pam3CSK4. FSL-1 is specific to TLR2 and TLR6, and Pam3CSK4 is recognized by TLR 2 and TLR1. Tables 2 and 3 detail the effect of the honey extracts on the inflammatory response in the HEKBlue ${ }^{\mathrm{TM}}-2$ cells.

By examining honey treatment using two ligands, the specific pathway through which honey might act could 
Table 3 The anti-inflammatory effect of honey extracts at five different concentrations (\% honey) compared with untreated cells, in the HEK-Blue ${ }^{\mathrm{TM}}-2$ cell line using the Pam3CSK 4 ligand

\begin{tabular}{|c|c|c|c|c|}
\hline Honey treatment & Concentration (\%) & Mean (SE) & Estimate $(95 \% \mathrm{Cl})$ & $P$-value \\
\hline \multirow[t]{6}{*}{ Phenolic manuka } & 0.0 & $\mathrm{I} .24(0.14)$ & 0.0 & \\
\hline & 5.3 & $1.05(0.09)$ & $-0.194(-0.396-0.008)$ & 0.0593 \\
\hline & 7.1 & $0.99(0.03)$ & $-0.248(-0.450$ to -0.046$)$ & 0.0184 \\
\hline & 10.7 & $0.95(0.14)$ & $-0.294(-0.496$ to -0.092$)$ & 0.0064 \\
\hline & 12.5 & $0.97(0.17)$ & $-0.274(-0.476$ to -0.072$)$ & 0.0102 \\
\hline & 14.3 & $0.87(0.17)$ & $-0.374(-0.576$ to -0.172$)$ & $9.27 \mathrm{E}-04$ \\
\hline \multirow[t]{6}{*}{ Phenolic kanuka } & 0.0 & $1.15(0.10)$ & 0.0 & \\
\hline & 5.3 & $0.98(0.07)$ & $-0.172(-0.298$ to -0.047$)$ & 0.0095 \\
\hline & 7.1 & $0.91(0.04)$ & $-0.238(-0.363$ to -0.112$)$ & 7.54E-04 \\
\hline & 10.7 & $0.77(0.08)$ & $-0.378(-0.504$ to -0.253$)$ & $3.28 \mathrm{E}-06$ \\
\hline & 12.5 & $0.69(0.09)$ & $-0.460(-0.585$ to -0.334$)$ & I.82E-07 \\
\hline & 14.3 & $0.63(0.07)$ & $-0.518(-0.643$ to -0.392$)$ & 2.67E-08 \\
\hline \multirow[t]{6}{*}{ Phenolic manuka/kanuka } & 0.0 & $1.09(0.08)$ & 0.0 & \\
\hline & 5.3 & $1.04(0.13)$ & $-0.050(-0.230$ to 0.130$)$ & 0.5669 \\
\hline & 7.1 & $1.03(0.10)$ & $-0.065(-0.245$ to 0.115$)$ & 0.4561 \\
\hline & 10.7 & $0.94(0.10)$ & $-0.152(-0.332$ to 0.028$)$ & 0.0933 \\
\hline & 12.5 & $0.93(0.15)$ & $-0.165(-0.345$ to 0.015$)$ & 0.0694 \\
\hline & 14.3 & $0.93(0.16)$ & $-0.168(-0.348$ to 0.012$)$ & 0.0658 \\
\hline \multirow[t]{6}{*}{ Phenolic clover } & 0.0 & $1.20(0.11)$ & 0.0 & \\
\hline & 5.3 & $1.13(0.12)$ & $-0.076(-0.289$ to 0.138$)$ & 0.4698 \\
\hline & 7.1 & $1.10(0.05)$ & $-0.099(-0.312$ to 0.115$)$ & 0.3469 \\
\hline & 10.7 & $1.08(0.17)$ & $-0.125(-0.338$ to 0.089$)$ & 0.2374 \\
\hline & 12.5 & $1.03(0.19)$ & $-0.173(-0.387$ to 0.040$)$ & 0.1064 \\
\hline & 14.3 & $0.98(0.17)$ & $-0.22(-0.434$ to -0.007$)$ & 0.0437 \\
\hline \multirow[t]{6}{*}{ Crude manuka } & 0.0 & $1.01(0.12)$ & 0.0 & \\
\hline & 5.3 & I.0I (0.04) & $-0.006(-0.138$ to 0.125$)$ & 0.9216 \\
\hline & 7.1 & $0.96(0.07)$ & $-0.052(-0.184$ to 0.079$)$ & 0.4086 \\
\hline & 10.7 & $0.95(0.08)$ & $-0.064(-0.195$ to 0.068$)$ & 0.3158 \\
\hline & 12.5 & $0.99(0.05)$ & $-0.024(-0.156$ to 0.108$)$ & 0.7012 \\
\hline & 14.3 & $0.91(0.07)$ & $-0.105(-0.236$ to 0.027$)$ & 0.1096 \\
\hline \multirow[t]{6}{*}{ Crude kanuka } & 0.0 & $\mathrm{I} .03(0.08)$ & 0.0 & \\
\hline & 5.3 & $1.06(0.07)$ & $0.023(-0.119$ to 0.165$)$ & 0.7337 \\
\hline & 7.1 & $\mathrm{I} .08(0.07)$ & $0.048(-0.094$ to 0.190$)$ & 0.4824 \\
\hline & 10.7 & $1.03(0.09)$ & $-0.003(-0.146$ to 0.139$)$ & 0.9600 \\
\hline & 12.5 & $\mathrm{I} .07(0.05)$ & $0.038(-0.104$ to 0.181$)$ & 0.5710 \\
\hline & 14.3 & $0.97(0.08)$ & $-0.066(-0.208$ to 0.076$)$ & 0.3378 \\
\hline \multirow[t]{6}{*}{ Crude manuka/kanuka } & 0.0 & $\mathrm{I} .02(0.08)$ & 0.0 & \\
\hline & 5.3 & $1.10(0.01)$ & $0.082(-0.054$ to 0.219$)$ & 0.2169 \\
\hline & 7.1 & $1.13(0.11)$ & $0.112(-0.025$ to 0.248$)$ & 0.1006 \\
\hline & 10.7 & $\mathrm{I} .05(0.1 \mathrm{I})$ & $0.030(-0.106$ to 0.167$)$ & 0.6423 \\
\hline & 12.5 & $\mathrm{I} .03(0.05)$ & $0.009(-0.127$ to 0.146$)$ & 0.8864 \\
\hline & 14.3 & $0.95(0.09)$ & $-0.068(-0.205$ to 0.068$)$ & 0.3015 \\
\hline \multirow[t]{6}{*}{ Crude clover } & 0.0 & $1.02(0.05)$ & 0.0 & \\
\hline & 5.3 & $1.13(0.08)$ & $0.110(-0.05 I$ to $0.27 I)$ & 0.1642 \\
\hline & 7.1 & $1.13(0.17)$ & $0.104(-0.056$ to 0.265$)$ & 0.1850 \\
\hline & 10.7 & $1.06(0.06)$ & $0.034(-0.126$ to 0.195$)$ & 0.6530 \\
\hline & 12.5 & $\mathrm{I} .08(0.06)$ & $0.056(-0.105$ to 0.216$)$ & 0.4700 \\
\hline & 14.3 & $0.95(0.04)$ & $-0.075(-0.235$ to 0.086$)$ & 0.3351 \\
\hline
\end{tabular}

Abbreviations: $\mathrm{Cl}$, confidence interval; SE, standard error; Pam3CSK4, Pam3CysSerLys4.

be determined. Honey treatment at all concentrations had little impact, as compared with that in untreated cells with FSL-1, except for the $14.3 \%$ concentration of the phenolic kanuka extract $(P=0.0390)$ and the $12.5 \%$ concentration of the crude manuka extract $(P=0.0462)$. Stronger anti-inflammatory effects were observed in the presence of the Pam3CSK 4 ligand, where the manuka and kanuka phenolics were particularly effective. At the highest concentrations, manuka honey significantly decreased the inflammatory response. With kanuka honey, all five concentrations significantly 
Table 4 The anti-inflammatory effect of honey extracts at five different concentrations (\% honey) compared with untreated cells, in the NOD2-WT cell line using the MDP ligand

\begin{tabular}{|c|c|c|c|c|}
\hline Honey treatment & Concentration (\%) & Mean (SE) & Estimate $(95 \% \mathrm{Cl})$ & $P$-value \\
\hline \multirow[t]{6}{*}{ Phenolic manuka } & 0.0 & $0.91(0.06)$ & 0.0 & \\
\hline & 5.3 & $1.02(0.17)$ & $0.108(-0.274$ to 0.490$)$ & 0.5154 \\
\hline & 7.1 & $1.01(0.20)$ & $0.092(-0.290$ to 0.474$)$ & 0.5766 \\
\hline & 10.7 & $1.09(0.13)$ & $0.172(-0.210$ to 0.554$)$ & 0.3127 \\
\hline & 12.5 & $0.94(0.15)$ & $0.027(-0.355$ to 0.408$)$ & 0.8707 \\
\hline & 14.3 & $0.88(0.0)$ & -0.031 ( -0.498 to 0.437$)$ & 0.8778 \\
\hline \multirow[t]{6}{*}{ Phenolic kanuka } & 0.0 & $1.00(0.08)$ & 0.0 & \\
\hline & 5.3 & $1.01(0.13)$ & $0.006(-0.536$ to 0.548$)$ & 0.9807 \\
\hline & 7.1 & $0.97(0.19)$ & $-0.032(-0.574$ to 0.510$)$ & 0.8888 \\
\hline & 10.7 & $0.90(0.18)$ & $-0.100(-0.642$ to 0.442$)$ & 0.6681 \\
\hline & 12.5 & $0.76(0.34)$ & $-0.240(-0.782$ to 0.302$)$ & 0.3195 \\
\hline & 14.3 & $0.72(0.0)$ & $-0.283(-0.947$ to $0.38 \mathrm{I})$ & 0.3372 \\
\hline \multirow[t]{6}{*}{ Phenolic manuka/kanuka } & 0.0 & $0.94(0.07)$ & 0.0 & \\
\hline & 5.3 & $1.04(0.06)$ & $0.096(-0.066$ to 0.259$)$ & 0.2029 \\
\hline & 7.1 & $0.94(0.07)$ & $-0.007(-0.169$ to 0.155$)$ & 0.9218 \\
\hline & 10.7 & $0.98(0.06)$ & $0.032(-0.131$ to 0.194$)$ & 0.6583 \\
\hline & 12.5 & $1.00(0.03)$ & $0.059(-0.103$ to 0.221$)$ & 0.4180 \\
\hline & 14.3 & $0.89(0.12)$ & $-0.05 \mathrm{I}(-0.214$ to $0.1 \mathrm{II})$ & 0.4779 \\
\hline \multirow[t]{6}{*}{ Phenolic clover } & 0.0 & $0.94(0.05)$ & 0.0 & \\
\hline & 5.3 & $1.00(0.02)$ & $0.068(-0.198$ to 0.334$)$ & 0.5647 \\
\hline & 7.1 & $0.97(0.01)$ & $0.031(-0.235$ to 0.297$)$ & 0.7931 \\
\hline & 10.7 & $1.13(0.24)$ & $0.193(-0.073$ to 0.459$)$ & 0.1304 \\
\hline & 12.5 & $0.94(0.07)$ & $0.005(-0.26 I$ to $0.27 \mathrm{I})$ & 0.9683 \\
\hline & 14.3 & $1.00(0.08)$ & $0.063(-0.203$ to 0.329$)$ & 0.5922 \\
\hline \multirow[t]{6}{*}{ Crude manuka } & 0.0 & I.II $(0.30)$ & 0.0 & \\
\hline & 5.3 & $0.99(0.01)$ & $-0.113(-0.488$ to $0.26 \mathrm{I})$ & 0.4970 \\
\hline & 7.1 & I.II (0.18) & $0.006(-0.368$ to 0.380$)$ & 0.9717 \\
\hline & 10.7 & $1.03(0.10)$ & $-0.072(-0.446$ to 0.302$)$ & 0.6621 \\
\hline & 12.5 & $0.91(0.01)$ & $-0.192(-0.566$ to 0.182$)$ & 0.2641 \\
\hline & 14.3 & $0.97(0.2 \mathrm{I})$ & $-0.134(-0.509$ to 0.240$)$ & 0.4239 \\
\hline \multirow[t]{6}{*}{ Crude kanuka } & 0.0 & $1.25(0.28)$ & 0.0 & \\
\hline & 5.3 & $1.13(0.24)$ & $-0.117(-0.5 \mathrm{II}$ to 0.276$)$ & 0.5033 \\
\hline & 7.1 & I.II (0.06) & $-0.133(-0.527$ to 0.260$)$ & 0.4499 \\
\hline & 10.7 & $0.98(0.12)$ & $-0.264(-0.657$ to 0.130$)$ & 0.1567 \\
\hline & 12.5 & $1.00(0.04)$ & $-0.242(-0.636$ to $0.15 \mathrm{I})$ & 0.1891 \\
\hline & 14.3 & $1.01(0.19)$ & $-0.232(-0.625$ to $0.16 \mathrm{I})$ & 0.2059 \\
\hline \multirow[t]{6}{*}{ Crude manuka/kanuka } & 0.0 & $1.23(0.34)$ & 0.0 & \\
\hline & 5.3 & $1.09(0.11)$ & $-0.142(-0.53 \mid$ to 0.247$)$ & 0.4170 \\
\hline & 7.1 & $1.14(0.06)$ & $-0.093(-0.48 \mathrm{I}$ to 0.296$)$ & 0.5913 \\
\hline & 10.7 & $1.10(0.11)$ & $-0.126(-0.515$ to 0.263$)$ & 0.4700 \\
\hline & 12.5 & $0.99(0.04)$ & $-0.233(-0.622$ to 0.156$)$ & 0.1990 \\
\hline & 14.3 & $0.90(0.17)$ & $-0.330(-0.719$ to 0.059$)$ & 0.0850 \\
\hline \multirow[t]{6}{*}{ Crude clover } & 0.0 & $1.19(0.23)$ & 0.0 & \\
\hline & 5.3 & $1.07(0.08)$ & $-0.122(-0.426$ to 0.183$)$ & 0.3762 \\
\hline & 7.1 & $1.12(0.13)$ & $-0.073(-0.377$ to $0.23 \mathrm{I})$ & 0.5874 \\
\hline & 10.7 & $1.07(0.02)$ & $-0.125(-0.429$ to 0.179$)$ & 0.3646 \\
\hline & 12.5 & $0.88(0.09)$ & $-0.315(-0.619$ to 0.011$)$ & 0.0442 \\
\hline & 14.3 & $0.91(0.13)$ & $-0.285(-0.589$ to 0.019$)$ & 0.0621 \\
\hline
\end{tabular}

Abbreviations: $\mathrm{Cl}$, confidence interval; NOD2-WT, nucleotide oligomerization domain 2-Wild Type; MDP, muramyl dipeptide; SE, standard error.

reduced the level of inflammation compared with that of no treatment. Treatment with the manuka/kanuka blend, the clover honey phenolics, and the crude extracts from all four honeys had no significant impact on the inflammatory response.
Figure 2 illustrates the anti-inflammatory effect observed using the HEK-Blue ${ }^{\mathrm{TM}}-2$ cell line when treated with the highest concentration (14.3\%) of honey phenolics and crude extracts and stimulated with Pam3CSK4. A significant decrease in inflammation was observed for each 


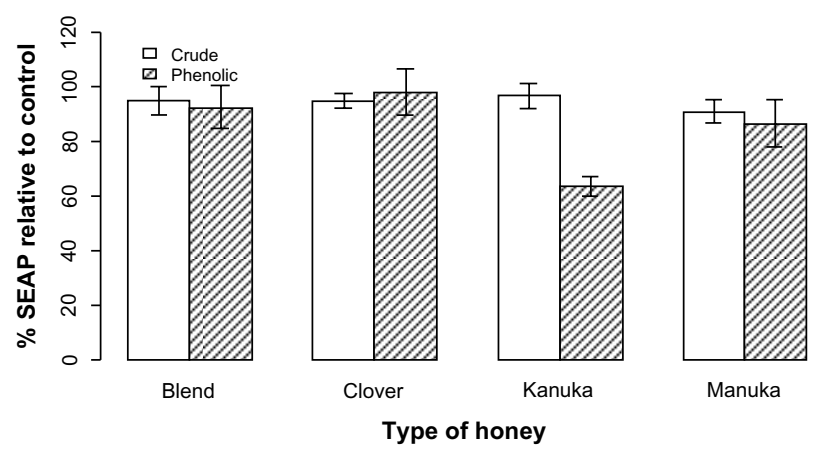

Figure 2 The anti-inflammatory effect of the four honey extracts when differentiated by honey phenolics and crude honey extracts.

Notes: Results are expressed as \% SEAP relative to control. The lower the value, the lower the level of SEAP, resulting in a lower anti-inflammatory effect. Blend is a mixture of crude manuka and kanuka honey.

Abbreviation: SEAP, secreted alkaline phosphatase.

extract compared with PMA (data not shown). Treatment with the phenolic and crude manuka/kanuka blend and clover extracts did not differ markedly from treatment with solvent. Treatment with the kanuka phenolic extract differed considerably from the solvent and the crude kanuka extract. The kanuka phenolic extract produced a comparable anti-inflammatory effect to that of ibuprofen (results not shown).

\section{Effect of honey extracts on inflammation in NOD2-WT cells}

Table 4 details the anti-inflammatory effect of honey treatment in NOD2-WT cells. There was no significant effect by the honeys, at any concentration, on the inflammatory response when compared with no treatment, with the exception of the $12.5 \%$ concentration of the crude clover extract, where a significant anti-inflammatory effect was observed $(P=0.0442)$.

\section{Discussion}

An inflammatory response was induced in HEK-Blue ${ }^{\mathrm{TM}}-2$, HEK-Blue ${ }^{\mathrm{TM}}-4$, and NOD2-WT cell lines using different ligands, to illustrate whether treatment with four honeys could produce an anti-inflammatory effect. The cell lines act through different signaling pathways (TLR2, TLR4, and NOD-like receptor [NLR] respectively). Thus, by being able to observe in which cell line(s) the honey treatment was effective, the pathway through which it produced an anti-inflammatory response could be demonstrated. The NOD2-WT cell line acts through the NLR signaling pathway and recognizes the MDP ligand. A substantial body of research exists to support the anti-inflammatory activity of a variety of honeys. This research, however, demonstrated that the honeys examined did not produce a significant antiinflammatory effect via either the TLR4 or NLR signaling pathway, observing a noticeable but not significant antiinflammatory activity with honey treatment.

Anti-inflammatory activity with honey treatment was observed in the HEK-Blue ${ }^{\mathrm{TM}}-2$ cell line and most significantly with kanuka honey. The kanuka phenolic extract was highly anti-inflammatory and had a greater effect than did the crude extract, indicating that a higher phenolic content correlates with its elevated anti-inflammatory activity. The manuka honey phenolics also had an anti-inflammatory effect in the HEK-Blue ${ }^{\mathrm{TM}}-2$ cells, although to a lesser extent than for the kanuka honey phenolics, with the highest concentrations producing a significant difference as compared with no treatment, thereby supporting the importance of polyphenols in the anti-inflammatory activity of honey. The anti-inflammatory effect by the kanuka and manuka honeys was strongest in the presence of the Pam3CSK4 ligand, indicating that the honeys act through the TLR1/ TLR2 signaling pathway. ${ }^{30}$ The anti-inflammatory activity of kanuka and manuka honeys is therefore pathway-specific. No significant effect was observed with honey treatment, at any concentration, in the NOD2-WT cell line, supporting the anti-inflammatory activity of honey being pathwayspecific. A hypothesis for the means by which kanuka honey exhibits anti-inflammatory activity is through the downregulation of proinflammatory mediators, such as IL-1 $\beta$ and NF-KB.

In wound healing, the inflammatory response is one phase of repair that is fundamental for normal healing. An elevated or prolonged inflammatory response is associated with a delay in wound repair, an increase in tissue damage, and the development of nonhealing, chronic wounds. By demonstrating significant anti-inflammatory activity, kanuka honey has the potential to be an effective treatment in preventing chronic wounds. International studies have shown that honey has a significant effect on the inflammatory response and support the use of honey in wound healing. ${ }^{18,24,31}$

Research has also shown a causal association between inflammatory diseases and treatment with honey. ${ }^{27,29,32}$ This study sought to investigate and further advance these findings. Antiinflammatory assays were conducted using HEK-Blue ${ }^{\mathrm{TM}}-2$, HEK-Blue ${ }^{\mathrm{TM}}-4$, and NOD2-WT cell lines, acting through different signaling pathways. The results demonstrate that kanuka honey exhibits anti-inflammatory effects in a pathway-specific manner. Further investigation would help to discover the exact mechanisms of action by which honeys act. 
HEK-Blue ${ }^{\mathrm{TM}}-2$ is a more sensitive cell line than is HEK-Blue ${ }^{\mathrm{TM}}-4$. The noticeable but not significant antiinflammatory effect observed by the honey phenolics in the HEK-Blue ${ }^{\mathrm{TM}}-4$ cells contrasts with the significant impact in the HEK-Blue ${ }^{\mathrm{TM}}-2$ cells, suggesting a reduced sensitivity rather than no anti-inflammatory activity. Further investigation using larger volumes of honey would be required to determine whether more significant results could be obtained.

\section{Conclusion}

New Zealand honeys have a well-established antiinflammatory effect in topical wound healing. However, less was known of their effect in vitro and of the signaling pathways through which they act. Treatment with kanuka and manuka honeys resulted in powerful anti-inflammatory effects in HEK-Blue ${ }^{\mathrm{TM}}-2$ cells, but not in the HEK-Blue ${ }^{\mathrm{TM}_{-}} 4$ or NOD2-WT cells. Specifically, the anti-inflammatory effect occurred via the TLR1/TLR2 signaling pathway. The effects suggest a correlation with the phenolic content of the honeys, with a higher phenolic content producing an elevated anti-inflammatory effect. Kanuka and manuka honeys therefore can have a positive impact on the inflammatory response associated with wound healing. Subsequent investigation is needed to determine the specific compounds present in the honeys that are agents responsible for their anti-inflammatory activity.

\section{Acknowledgments}

The authors express their appreciation to Comvita Innovation (Comvita New Zealand Ltd) for their assistance in conducting the research, and to the Department of Nutrition and the Auckland Cancer Society Research Centre laboratories (The University of Auckland) for their help and support, particularly Dr Nishi Karunasinghe and Noha Ahmed Nasef. Sincere thanks to Airborne Honey Ltd and to B Stevenson (Comvita New Zealand Ltd) for the provision of the New Zealand honey samples.

\section{Disclosure}

Victoria Tomblin received a research scholarship and funding for materials from Comvita New Zealand Ltd. Ralf Schlothauer is an employee of Comvita New Zealand Ltd. The authors report no other conflicts of interest in this work.

\section{References}

1. Lee DS, Sinno S, Khachemoune A. Honey and wound healing: an overview. Am J Clin Dermatol. 2011;12(3):181-190.

2. Molan PC. Using honey in wound care. IJCA. 2006;3(2):21-24.

3. Molan PC. The role of honey in the management of wounds. $J$ Wound Care. 1999;8(8):415-418.
4. Mathews KA, Binnington AG. Wound management using honey. Compendium for the Continuing Education of the Practicing Veterinarian. 2002;24(1):53-60.

5. Subrahmanyam M. Honey dressing versus boiled potato peel in the treatment of burns: a prospective randomized study. Burns. 1996;22(6): 491-493.

6. Bogdanov S, Jurendic T, Sieber R, Gallmann P. Honey for nutrition and health: a review. J Am Coll Nutr. 2008;27(6):677-689.

7. Khan FR, Ul Abadin Z, Rauf N. Honey: nutritional and medicinal value. Int J Clin Pract. 2007;61(10):1705-1707.

8. Molan PC. Re-introducing honey in the management of wounds and ulcers - theory and practice. Ostomy Wound Manage. 2002;48(11): $28-40$.

9. Tonks AJ, Dudley E, Porter NG, et al. A 5.8-kDa component of manuka honey stimulates immune cells via TLR4. J Leukoc Biol. 2007;82(5): $1147-1155$.

10. Mwipatayi BP, Angel D, Norrish J, Hamilton MJ, Scott A, Sieunarine K. The use of honey in chronic leg ulcers: a literature review. Primary Intention. 2004;12(3):107-108, 110-112.

11. Steinhorn G, Sims IM, Carnachan SM, Carr AJ, Schlothauer R. Isolation and characterisation of arabinogalactan-proteins from New Zealand kanuka honey. Food Chemistry. 2011;128(4): 949-956.

12. Lund LR, Romer J, Bugge TH, et al. Functional overlap between two classes of matrix-degrading proteases in wound healing. EMBO J. 1999; 18(17):4645-4656.

13. Pilcher BK, Dumin JA, Sudbeck BD, Krane SM, Welgus HG, Parks WC. The activity of collagenase- 1 is required for keratinocyte migration on a type I collagen matrix. J Cell Biol. 1997;137(6):1445-1457.

14. Majtan J, Kumar P, Majtan T, Walls AF, Klaudiny J. Effect of honey and its major royal jelly protein 1 on cytokine and MMP-9 mRNA transcripts in human keratinocytes. Exp Dermatol. 2010;19(8): e73-e79.

15. Schultz GS, Mast BA. Molecular analysis of the environments of healing and chronic wounds: cytokines, proteases and growth factors. Primary Intention. 1999;7(1):7-14.

16. Lee Y, Kim H, Kim S, Kim KH, Chung JH. Activation of toll-like receptors 2,3 or 5 induces matrix metalloproteinase- 1 and -9 expression with the involvement of MAPKs and NF-kappaB in human epidermal keratinocytes. Exp Dermatol. 2010;19(8):e44-e49.

17. Chung TW, Moon SK, Chang YC, et al. Novel and therapeutic effect of caffeic acid and caffeic acid phenyl ester on hepatocarcinoma cells: complete regression of hepatoma growth and metastasis by dual mechanism. FASEB J. 2004;18(14):1670-1681.

18. Hämäläinen M, Nieminen R, Vuorela P, Heinonen M, Moilanen E. Anti-inflammatory effects of flavonoids: genistein, kaempferol, quercetin, and daidzein inhibit STAT-1 and NF-kappaB activations, whereas flavone, isorhamnetin, naringenin, and pelargonidin inhibit only NF-kappaB activation along with their inhibitory effect on iNOS expression and $\mathrm{NO}$ production in activated macrophages. Mediators Inflamm. 2007;2007:45673.

19. Brandner JM, Zacheja S, Houdek P, Moll I, Lobmann R. Expression of matrix metalloproteinases, cytokines, and connexins in diabetic and nondiabetic human keratinocytes before and after transplantation into an ex vivo wound-healing model. Diabetes Care. 2008;31(1):114-120.

20. Trengove NJ, Stacey MC, MacAuley S, et al. Analysis of the acute and chronic wound environments: the role of proteases and their inhibitors. Wound Repair Regen. 1999;7(6):442-452.

21. Diegelmann RF, Evans MC. Wound healing: an overview of acute, fibrotic and delayed healing. Front Biosci. 2004;9:283-289.

22. van den Berg AJ, van den Worm E, van Ufford HC, Halkes SB, Hoekstra MJ, Beukelman CJ. An in vitro examination of the antioxidant and anti-inflammatory properties of buckwheat honey. $J$ Wound Care. 2008;17(4):172-174, 176.

23. Leong AG, Herst PM, Harper JL. Indigenous New Zealand honeys exhibit multiple anti-inflammatory activities. Innate Immun. 2012;18(3): $459-466$. 
24. Kassim M, Achoui M, Mustafa MR, Mohd MA, Yusoff KM. Ellagic acid, phenolic acids, and flavonoids in Malaysian honey extracts demonstrate in vitro anti-inflammatory activity. Nutr Res. 2010;30(9):650-659.

25. Khalil M, Sulaiman SA, Boukraa L. Antioxidant properties of honey and its role in preventing health disorder. The Open Nutraceuticals Journal. 2010;3(1):6-16.

26. Pyrzynska K, Biesaga M. Analysis of phenolic acids and flavonoids in honey. $\operatorname{Tr} A C$. 2009;28(7):893-902.

27. Mahgoub AA, el-Medany AH, Hagar HH, Sabah DM. Protective effect of natural honey against acetic acid-induced colitis in rats. Trop Gastroenterol. 2002;23(2):82-87.

28. Medhi B, Prakash A, Avti PK, Saikia UN, Pandhi P, Khanduja KL. Effect of Manuka honey and sulfasalazine in combination to promote antioxidant defense system in experimentally induced ulcerative colitis model in rats. Indian J Exp Biol. 2008;46(8):583-590.
29. Prakash A, Medhi B, Avti PK, Saikia UN, Pandhi P, Khanduja KL. Effect of different doses of Manuka honey in experimentally induced inflammatory bowel disease in rats. Phytother Res. 2008;22(11): 1511-1519.

30. Uhlen M, Oksvold P, Fagerberg L, et al. Towards a knowledge-based Human Protein Atlas. Nat Biotechnol. 2010;28(12):1248-1250.

31. Al-Waili NS, Boni NS. Natural honey lowers plasma prostaglandin concentrations in normal individuals. J Med Food. 2003;6(2):129-133.

32. Bilsel Y, Bugra D, Yamaner S, Bulut T, Cevikbas U, Turkoglu U. Could honey have a place in colitis therapy? Effects of honey, prednisolone, and disulfiram on inflammation, nitric oxide, and free radical formation. Dig Surg. 2002;19(4):306-311; discussion 311-312.

\section{Publish your work in this journal}

The International Journal of General Medicine is an international, peer-reviewed open-access journal that focuses on general and internal medicine, pathogenesis, epidemiology, diagnosis, monitoring and treatment protocols. The journal is characterized by the rapid reporting of reviews, original research and clinical studies across all disease areas.
A key focus is the elucidation of disease processes and management protocols resulting in improved outcomes for the patient. The manuscript management system is completely online and includes a very quick and fair peer-review system. Visit http://www.dovepress.com/ testimonials.php to read real quotes from published authors. 